\title{
$\mathrm{S} 10$
}

\section{Sub-salt Imaging through Pre-stack Depth Migration - A Case Study from Offshore Egypt}

H. El Meligy (Statoil Egypt), M. Sheath (StatoilHydro), J. Høyen* (StatoilHydro), D. Renshaw (StatoilHydro), Ø. Skinnemoen (StatoilHydro), A. Issa (WesternGeco), W. Badr (WesternGeco), M. Abdelaty (WesternGeco), E. Shady (WesternGeco), M. Hărde (StatoilHydro) \& C. Jebsen (StatoilHydro)

\section{SUMMARY}

The Middle East hosts a wide range of different geological setting, a large number of which exhibit structural complexity and hence can benefit from depth imaging. These structurally complex areas range from over thrust zones on the U.A.E - Oman border to salt structures in the Gulf of Suez and fault shadow problems in the Western Desert of Egypt in addition to offshore Egypt 


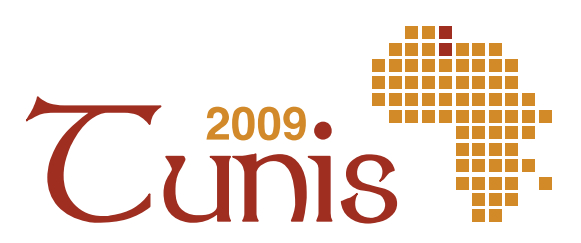

The Middle East hosts a wide range of different geological setting, a large number of which exhibit structural complexity and hence can benefit from depth imaging. These structurally complex areas range from over thrust zones on the U.A.E - Oman border to salt structures in the Gulf of Suez and fault shadow problems in the Western Desert of Egypt in addition to offshore Egypt.

In the Offshore Egypt the presence of salt structures can cause considerable distortion of the sub-salt seismic image. This distortion is due to strong vertical and lateral variations, which lead to refraction of seismic waves. Pre-stack depth imaging is considered as viable and ultimate tool for accurate delineation of sub-salt reflectors in this geological environment. To achieve the best seismic image an optimal interval velocity/ depth model has to be built. This in itself presents a substantial challenge when working in areas with complicated geological structures. In this case study, an iterative process of velocity model building is presented, which closely integrates seismic data with geological information, to derive a sub-surface velocity distribution that enables production of the best image.

Also this study will show how implementation of Pre-stack depth migration can be used to enhance and improve imaging on a narrow azimuth towed streamer dataset from offshore Egypt's Mediterranean Sea.

The area of interest is extremely challenging for imaging due to highly rogues seabed which is characterized by rapid changes in water depth, complex near surface geology, a deep complex salt layer and Plio-Pleistocene turbidite depositional sequence along Nile delta cone (figure 1).

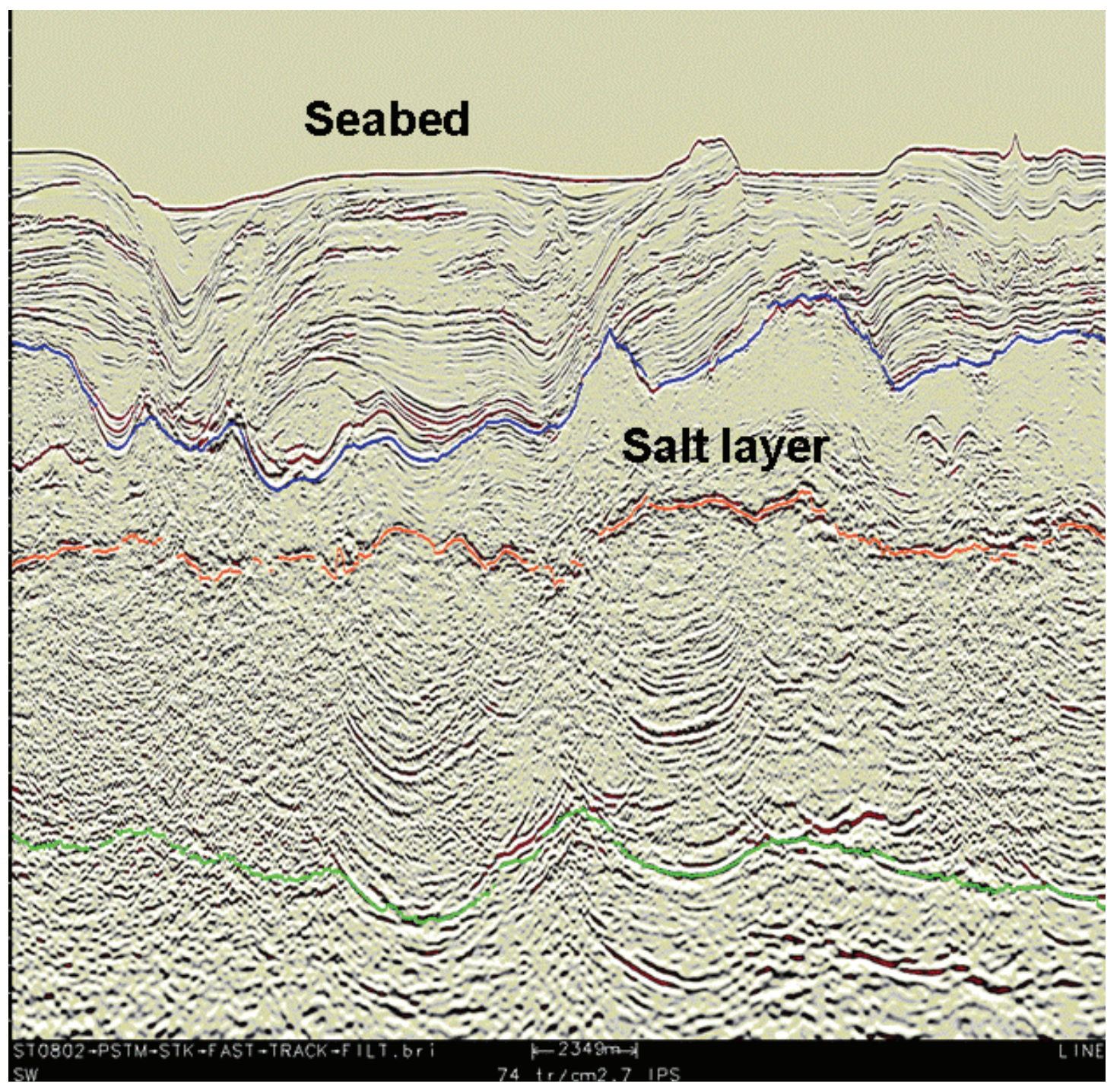

Tunis $2009-4^{\text {th }}$ North African/Mediterranean Petroleum and Geosciences Conference \& Exhibition Tunis, Tunisia, 2 - 4 March 2009 
Because of geological complexity of the data set and short wavelength changes in velocities, a high resolution hybrid Cell-based tomography (CIP-Tomo) workflow is needed to achieve both lateral and vertical resolution in our velocity model.

CIP-Tomo is a cell-based tomography algorithm which calculates updates to the input velocity model so as to globally minimize the residual moveout for all reflections. Required inputs for CIP-Tomo are picks of reflected events for a number of CIPs, a 3D dip field, and an initial velocity field. 